\title{
In vitro Shoot Regeneration from Roots and Leaf Discs of Passiflora cincinnata Mast.
}

\author{
Simone Pacheco Lombardi ${ }^{1}$, Ilene Ribeiro da Silva Passos ${ }^{3}$, Maria Cristina Stolf Nogueira ${ }^{4}$ \\ and Beatriz Appezzato-da-Glória ${ }^{2 *}$ \\ ${ }^{2}$ Departamento de Ciências Biológicas; Escola Superior de Agricultura "Luiz de Queiroz"; Universidade de São \\ Paulo; 13418-900; Piracicaba - SP - Brasil. ${ }^{3}$ Centro de Pesquisa e Desenvolvimento de Recursos Genéticos \\ Vegetais; Instituto Agronômico de Campinas; ${ }^{4}$ Departamento de Ciências Exatas; ESALQ-USP; Piracicaba - SP - \\ Brasil
}

\begin{abstract}
Different concentrations of 6-benzyladenine (6-BA) were used in vitro to induce buds in three types of explants: leaf discs, root segments and the seedling itself obtained from in vitro seed germination of Passiflora cincinnata Mast. The $0.5 \mathrm{mg} . \mathrm{L}^{-1}$ 6-BA concentration was most suitable for all the three explants, however, bud formation time and means (direct/indirect) were different for each type of explant. In seedlings used as explants, it had shoot regeneration from the primary root. Histological events leading to bud formation via meristemoids were described. The origin was indirect in leaf discs, with callus formation in subepidermal cells of the chlorophyll parenchyma layers. In root segments and in seedling roots, the buds were formed directly in the pericycle (in roots with some secondary structure) and in the vascular cambium (at the initial phase of secondary structure). Also, indirect buds originated from meristemoids which were formed around the callus.
\end{abstract}

Keys words: Anatomical, organogenesis, 6-benzyladenine, passionfruit.

\section{INTRODUCTION}

Brazil holds a privileged condition regarding the genetic resources of Passiflora, since the largest center of passionfruit dispersion is located in the Central-North region of the country (Sousa and Meletti 1997). It is fundamental to study such species, whether edible or not, viewing the expansion of the commercial cultivation of this fruit and the identification of materials resistant to the diseases occurring in the main species of economical interest Passiflora edulis Sims. This species is not a perennial crop. It is not a clone. It is propagated by seeds. Conversely, we need to replace the crop in the field every three years because of the incidence of several diseases like bacterioses and viruses.

In addition to the medicinal properties (Agra et al. 1996), Passiflora cincinnata Mast., an edible species, is resistant to the bacterial blight caused by bacterium Xanthomonas campestris f. sp. passiflorae (São José 1994), and presents a potential to commercialization, therefore constituting an interesting genotype for breeding programs. To fuse and regenerate protoplasts between Passiflora cincinnata and P. edulis, it is crucial to have an explant with an optimal regeneration capacity, since $P$. edulis does not have.

\footnotetext{
${ }^{*}$ Author for correspondence
} 
Current breeding tools include genetical transformation and protoplast fusion, hence in vitro regeneration studies are essential. Several works on in vitro regeneration have been published on a few Passiflora species (Dornelas and Vieira 1994; Appezzato-da-Glória et al. 1999; Monteiro et al. 2000; Hall et al. 2000; Biasi et al. 2000; Reis et al. 2003; Becerra et al. 2004). In order to fully use these tools, in vitro plant regeneration processes can be assayed and characterized by histological and morphological analysis of plant material. Histological studies are important not only to confirm the in vitro regeneration means, but also to determine the cell types from which somatic embryos or shoot buds appear (Vieira and Appezzato-da-Glória 2001).

The goal of this work was to verify the organogenetic potential of three different types of $P$. cincinnata explants, and to determine the competent cells for each explant.

\section{MATERIALS AND METHODS}

Seeds sterilization, germination and culture media of Passiflora cincinnata Mast.

The $P$. cincinnata Mast. seeds used in our experiments were collected from the germplasm collection of the Instituto Agronômico de Campinas (IAC), experimental station of Monte Alegre do Sul - SP. Seeds were detergent-washed and rinsed in running water, then dipped in $70 \%$ ethanol for 40 seconds, using a clean cloth to remove the remaining aril. The seeds were then dipped in water for six hours to break the dormancy. The following stages of seeds decontamination were carried out in an aseptic laminar flow hood. Seeds were surface sterilized in a $2 \%$ calcium hypochlorite solution for 20 minutes, rinsed in a cloridric acid solution $(0,005 \mathrm{~N})$ and rinsed three times with sterile double-distilled water under agitation for 20 minutes. The seeds were sectioned (two small cut, $1 \mathrm{~mm}$ thick, with a tip of scalpel) and germinated in tubes $(375 \mathrm{~mL})$ containing $30 \mathrm{~mL}$ of culture medium composed of half the basic salts and vitamin concentration of Murashige and Skoog (1962), supplemented with 15 g.L L $^{-1}$ sucrose. The $\mathrm{pH}$ of the medium was adjusted to 5.8 before adding the $6 \mathrm{~g} . \mathrm{L}^{-1}$ agar. Medium was autoclaved at $120^{\circ} \mathrm{C}$ for 40 minutes. Seeds were incubated at photoperiod conditions of 16/8 hours, clear/dark respectively, and $25 \pm 1^{\circ} \mathrm{C}$ temperature.

\section{In vitro organogenesis}

Twenty days following the in vitro germination, some intact seedlings were used as explants to 6BA treatments as described bellow. The remaining seedlings were transferred for MS medium with 30 g. $\mathrm{L}^{-1}$ sucrose plus $5 \%$ coconut water (concentration established for species in laboratory, data not show) for additional growth to obtain leaf discs and root segments. The $\mathrm{pH}$ of the medium was adjusted to 5.8 before adding the 6 g. $\mathrm{L}^{-1}$ agar. Medium was autoclaved at $120^{\circ} \mathrm{C}$ for 40 minutes. Culture condition was the same mentioned in germination conditions. Following 28 days in growth medium, root segments and leaf discs explants were obtained. The roots were segmented $1-2 \mathrm{~cm}$ long starting in the root insertion into the plant and 5-mm leaf discs were obtained from young, well nourished and expanded leaves, through a cork drill. The treatments corresponded to MS medium with 30 g. $\mathrm{L}^{-1}$ sucrose plus $5 \%$ coconut water at five different concentrations of 6 -BA $(0.0 ; 0.5 ; 1.0$; $1.5 ; 2.0 \mathrm{mg}$. $\left.\mathrm{L}^{-1}\right)$. Each culture tubes $(375 \mathrm{~mL})$, containing $30 \mathrm{~mL}$ of medium, were inoculated leaf discs with the abaxial surface of the leaf in contact with the medium and roots segments in the horizontal position in the medium culture. The experimental design was completely randomized, with five treatments and fifteen repetitions. For the leaf explants and root segment five explants per tube it corresponds to a repetition while for the seedling explant only one explant was placed per tube (repetition). After 28 days, the explants were evaluated as to the organogenic ability and transferred to a medium of the same formulation. The evaluation was repeated 56 days later and the number of buds per explant counted.

\section{Anatomical studies of in vitro organogenesis}

The three explants, leafs, roots and seedlings, were collected periodically $(7,14,21,28,35,42,49,56$ days) along the experiment viewing the histological characterization of the organogenic process. The samples were fixed in a Karnovsky solution (Karnovsky 1965), taken to a vacuum pump to remove intercellular air, dehydrated in ethylic series and infiltrated with a Leica metacrylate glycol resin. The sections $(5 \mu \mathrm{m}$ thick), made through a manual rotary microtome 
(Leica), were stained with $0.05 \%$ toluidine blue in a phosphate buffer and citric acid (Sakai 1973) and mounted with "Entellan" synthetic resin (Merck).

\section{Statistical analysis}

The statistical analysis was performed by the Statistical Analysis System (SAS 2000) 8.0 system considering a completely randomized design with 15 repetitions. The square root was used for the number of organogenic explants and mean number of buds in the leaf disc and seedling experiment, and logarithm transformation was used to analyze the mean number of buds in the root segment experiment. The mean data transformed were compared by the Tukey's test with a 0.05 confidence interval.

\section{RESULTS AND DISCUSSION}

\section{Anatomical analysis \\ Leaf discs}

Bud formation in leaf discs was indirect in the callus (Fig. 1-4) resulting from cell proliferation in the chlorophyll parenchyma. The beginning of the anatomical changes was observed on the $14^{\text {th }}$ day of culture. In some chlorophyll parenchyma regions, periclinal and anticlinal cell divisions (Fig. 2) were intensified during the culture time, forming a callus along the explant surface. Meristemoids composed of small cells (Fig. 2) with a dense cytoplasm and conspicuous nucleus, were formed on the surface callus layers. Adventitious buds derived from these meristemoids (Fig. 1,3-4). In Bauhinia forficata Link, Melo et al. (2000) report the same meristemoid formation process, with different origin tissue of the calluses only. In P. edulis f. flavicarpa, Appezzato-da-Glória et al. (1999) observed the same anatomical changes under light and BAP conditions in leaf explants, with cellular divisions starting by day 14 of culture in the subepidermal layers, forming meristemoids, and by day 28 , forming the shoot bud.

Several developmental stages were observed within the same explant due to continuous and simultaneous callus and bud formation. The asynchronous process of the in vitro organogenesis may be explained by the achievement of competence and determination of different-stage cells. The lacking synchrony in the organogenic process was also reported in P. edulis f. flavicarpa (Dornelas and Vieira 1994; Appezzato-da-Glória et al. 1999; Biasi et al. 2000).

\section{Root segments and seedlings}

In vitro organogenesis in $P$. cincinnata from the root segment occurred both directly and indirectly. In seedlings used as explants, it only occurred directly in the roots. In both explants the direct origin of the bud (Fig. 5-9 and 12-15) depended on the development stage of the root.

At the early secondary growth (Fig. 6-7) the shoot bud arisen endogenously from the pericycle, and the vascular connection between bud and root was acropetally. At the sprouting area of the shoot bud the root had split epidermis and cortex (Fig. 7). At the more advanced secondary structure (Fig. 8-9), the meristemoid that was supposed to develop in the shoot bud derived from the vascular cambium. In the indirect organogenesis from the root segments (Fig. 10-11) calluses formed, especially in the root cut ends. In some root sectors, the pericycle cells had successive divisions forming the callus (Fig. 11). In the peripheral layers of callus, resulting from the pericycle proliferation, meristemoid-deriving shoot buds developed (Fig. 11).

Unlike the reported for $P$. cincinnata, in Curcuma zedoaria (Melo et al. 2001), indirect organogenesis was observed in root segments, although the cellular divisions for callus formation occurred in the cortical parenchyma. Likewise, Peres et al. (2001) observed in anatomical analysis of in vitro wild tomato (Lycopersicon peruvianum, $L$. chilense and L. hirsutum) the formation of buds in the roots, which can also occur direct or indirectly, depending on the genotype used. According to the authors, indirect bud formation occurs together with callus formation, in the cortical parenchyma, via meristemoids, in peripheral layers. 

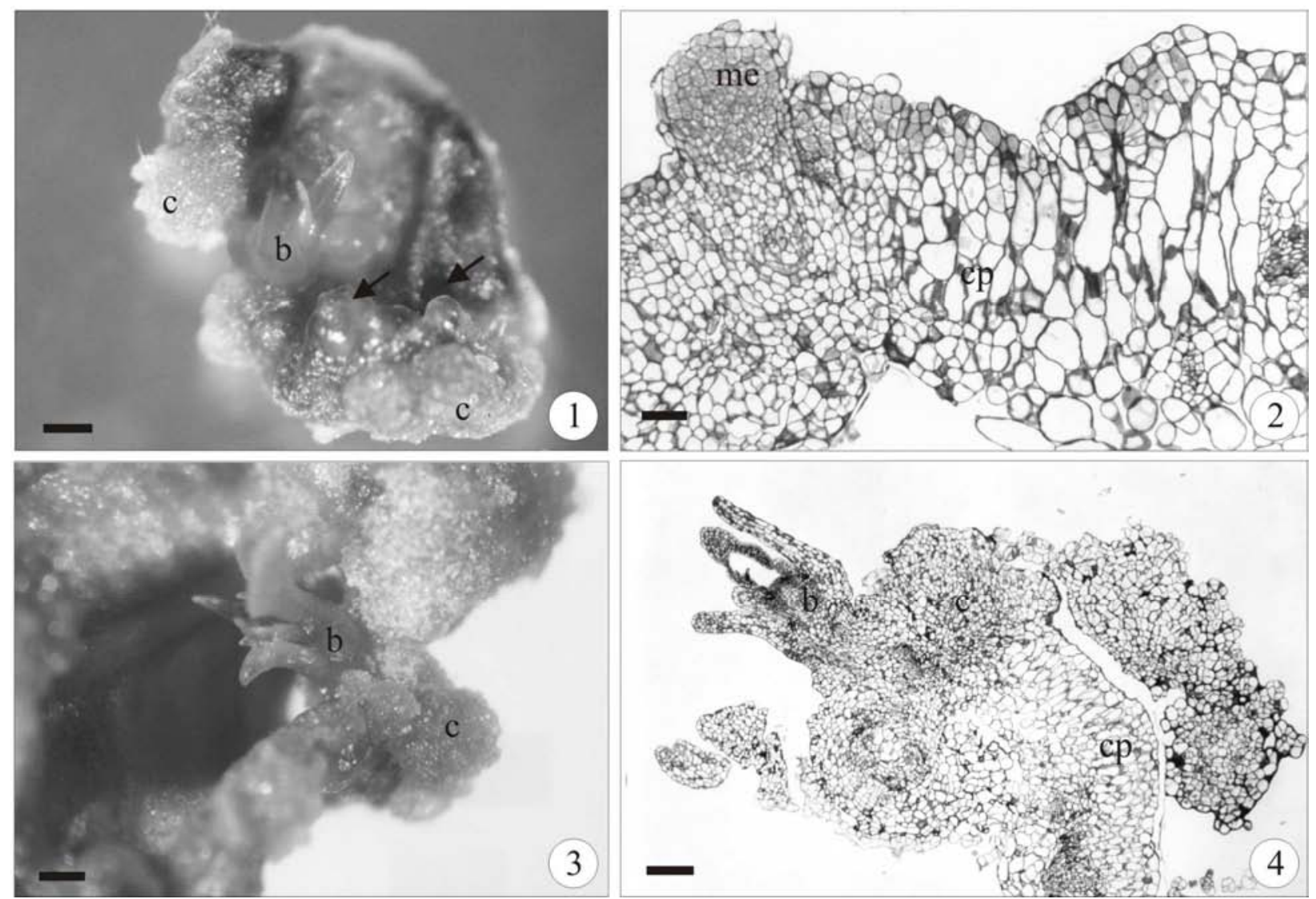

Figure 1-4 - Indirect in vitro organogenesis in the leaf disc of Passiflora cincinnata in MS medium supplemented with coconut water $(5 \%)$ and $1.0 \mathrm{mg} . \mathrm{L}^{-1}$ 6-BA about the day 21 (1-2), and $0.5 \mathrm{mg} . \mathrm{L}^{-1}$ 6-BA about the day 28 (3-4). (1) Bud formation (b) and meristemoids (arrows) in callus (c). (2) Cross section of mesophyll, detail of the subepidermal layer divisions originating the meristemoid (me). (3) Bud detail (b) formed in callus. (4) Cross section of leaf disc showing the formation of a bud. ( $\mathrm{cp}=$ chlorophyll parenchyma). (Bars $=450 \mu \mathrm{m}(\mathbf{1 , 3}), 66.6 \mu \mathrm{m}(\mathbf{2}), 199 \mu \mathrm{m}(\mathbf{4}))$.

Effect of growth regulator 6-benzyladenine (6BA) on in vitro organogenesis of Passiflora cincinnata Mast.

\section{Leaf discs}

The highest induction of organogenesis (Table 1) was observed in leaf discs after 28 days in 0.5 mg. $L^{-1}$ 6-BA, although no statistical difference was observed from that of $1.5 \mathrm{mg} . \mathrm{L}^{-1} 6-\mathrm{BA}$. By day 56 , the responses were homogenous for 0.5 , 1.0 and $1.5 \mathrm{mg} . \mathrm{L}^{-1}$ 6-BA treatments, therefore showing an apparent - if not significant - addition regarding the responses by day 28 for these treatments. Thus, for an optimized regeneration protocol, it was essential for explants to be exposed for 56 days to plant hormone 6-BA, an organogenesis inducer.

The formation of buds in leaf discs was observed after the formation of calluses at the explant ends. The indirect organogenesis in $P$. cincinnata occurred only in culture medium containing 6-BA regulator, which was also observed in internode segments of $P$. edulis f. flavicarpa (Biasi et al. 2000) and in leaf discs of Passiflora suberosa (Monteiro et al. 2000). 


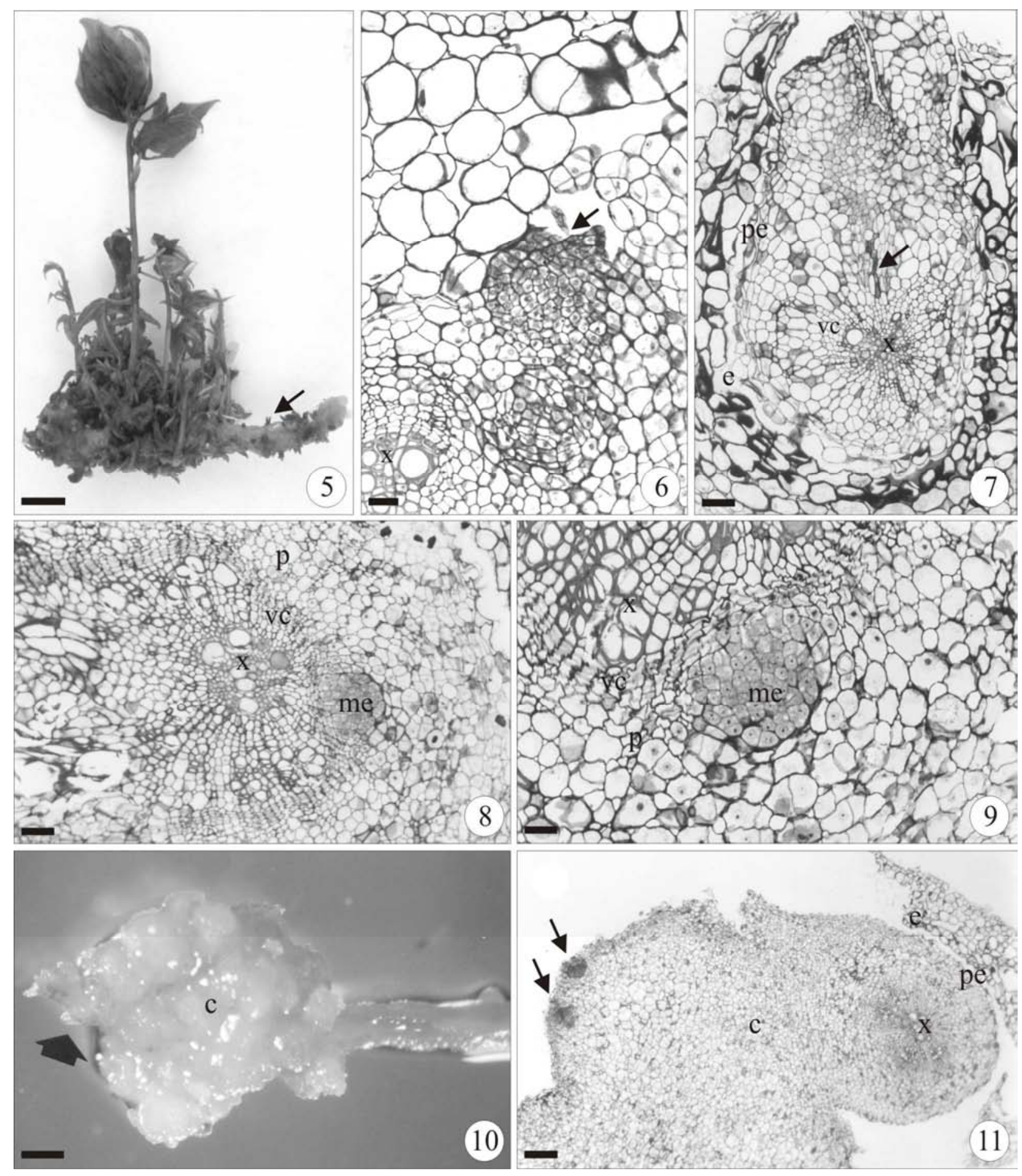

Figure 5-11 - Direct (5-9) and indirect (10-11) in vitro organogenesis in the root segment of Passiflora cincinnata in MS medium with coconut water (5\%) supplemented with different concentrations of 6-BA. (5) Bud formation in lateral root of explants in $1.0 \mathrm{mg} . \mathrm{L}^{-1}$ 6-BA about the day 42. (6-7) Cross section of the root segment showing a meristemoid (arrow) rising from the pericycle in hormone free treatment about the day 14 (6) and 28 (7). (8-9) Meristemoid (me) origin in the vascular cambium in $0,5 \mathrm{mg} . \mathrm{L}^{-1} 6-\mathrm{BA}$ about the day 14. (1011) Bud formation (arrow) (10) and two meristemoids (arrows) (11) in the peripheral layers of callus (c) in the end of lateral root in $0.5 \mathrm{mg}$. $\mathrm{L}^{-1} 6-\mathrm{BA}$ about the day 14 . ( $\mathrm{vc}=$ vascular cambium, $\mathrm{e}=$ endodermis, $\mathrm{p}=$ phloem, $\mathrm{x}=$ xylem). (Bars $=1.5 \mathrm{~cm}(\mathbf{5}), 33.3 \mu \mathrm{m}(\mathbf{6 - 7}, \mathbf{9})$, $137.5 \mu \mathrm{m}$ (8), $620 \mu \mathrm{m}$ (10), $328 \mu \mathrm{m}$ (11)). 

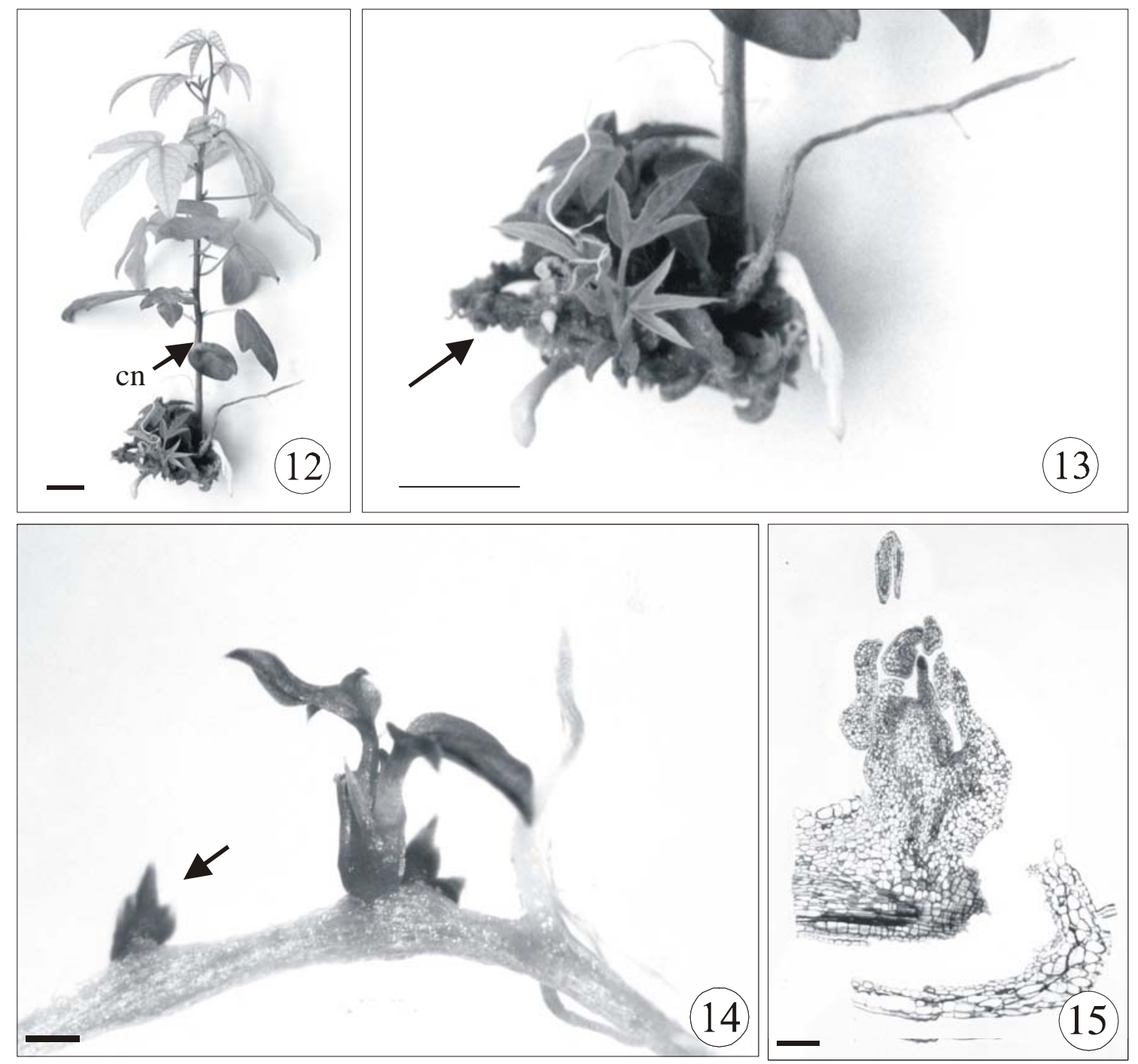

Figure 12-15 - Passiflora cincinnata seedling explant in MS medium supplemented with coconut water $(5 \%)$ and $2.0 \mathrm{mg} . \mathrm{L}^{-1} 6$-BA about the day $56(\mathbf{1 2 - 1 3})$ and $0.5 \mathrm{mg} . \mathrm{L}^{-1} 6$-BA about the day 28 (14-15). Direct organogenesis is verified in the primary root (arrow) of the seedling (13-14). (13) Detail of the primary root with many shoot formation. (15) Cross section of seedling primary root, detail of the bud formation indicated by the arrow in figure 14. $(\mathrm{nc}=$ cotiledonare node $)($ Bars $=1.0 \mathrm{~cm}(\mathbf{1 2 - 1 3}), 620 \mu \mathrm{m} \mathrm{(14),} 199$ $\mu \mathrm{m}(\mathbf{1 5}))$.

In $P$. edulis f. flavicarpa, the direct organogenesis in leaf discs described by Dornelas and Vieira (1994), at 28 days of culture in MS medium with $1.0 \mathrm{mg}$. $\mathrm{L}^{-1}$ de $6-\mathrm{BA}$, had a regeneration response of $41.7 \%$. Likewise, in wild species (P. molissima, $P$. giberti, $P$. maliformis and $P$. amethystina), Dornelas and Vieira (1994) observed direct organogenesis on leaf disc surfaces in $1.0 \mathrm{mg} . \mathrm{L}^{-1}$ 6-BA medium. By day 28 of culture, $P$. giberti and P. molissima had 70 and $10 \%$ of organogenic explants, respectively (Dornelas and Vieira 1994). In $P$. cincinnata, however, the best organogenic response was obtained in a $0.5 \mathrm{mg}$. $\mathrm{L}^{-1}$ de $6-\mathrm{BA}$ medium, in which by day 28 of culture $29 \%$ of explants formed buds, and by day 56 presented $54 \%$ of organogenic explants (Table 1).

In the absence of 6-BA regulator, no bud formation was observed and the higher concentration (2.0 mg.L $\mathrm{L}^{-1}$ 6-BA) was not favorable to bud formation. For P. edulis f. flavicarpa, 2.0 
$\mathrm{mg} \cdot \mathrm{L}^{-1}$ 6-BA concentration was satisfactory to induce organogenesis, while higher doses at 2.0 mg. $\mathrm{L}^{-1}$ injured bud growth (Dornelas and Vieira 1994; Biasi et al. 2000). Kantharaj and Dodd (1990) performed a $P$. edulis micropropagation experiment in node explants, testing two sucrose concentrations ( 2 and 3\%), absence and presence of coconut water $(20 \%)$, combining three BAP concentrations $\quad\left(1.0, \quad 2.0\right.$ and $\left.3.0 \quad \mathrm{mg} . \mathrm{L}^{-1}\right)$. According to the authors, the presence of coconut water indicated an increased production of shoots per explant.

\section{Root segments}

The best response of organogenesis was observed in root segments. The efficiency of shoot formation not differed among concentrations; homogenous responses were observed between treatments of both 28 and 56 days, including the hormone-free treatment. An exception is observed (Table 1) for the $2.0 \mathrm{mg} . \mathrm{L}^{-1}$ 6-BA treatment, in which the percentage of regenerative explants was statistically lower in both dates. It was interesting to note that the root isolated from the seedling was enough for the competent cells of this explant to be organogenesis-induced. In the absence of 6-BA, the number of buds formed was 2.25 , with no significant difference from the values obtained in 1.0 and $1.5 \mathrm{mg} . \mathrm{L}^{-1}$ concentrations (Table 2).

The root isolation may have changed the auxin/cytokinin endogenous balance, favoring cytokinin, in that the roots are the plant's main cytokinin producing centers (Van Staden and Smith 1978). The endogenous concentration of cytokinin may have influenced the response of treatment 5 corresponding to higher 6-BA concentration used $\left(2.0 \mathrm{mg} . \mathrm{L}^{-1}\right)$, causing reduced organogenic response (Table 2). Similarly, Peres et al. (2001) observed a high bud regeneration ability in root segments in wild tomatoes Lycopersicon peruvianum, $L$. chilense and $L$. hirsutum. According to the authors, the bud formation occurred two weeks later in zeatin medium.

Table 1 - Effect of 6-BA on the percentage of explant regeneration responses of Passiflora cincinnata Mast. about the day 28 and 56 of culture on MS medium supplemented with $5 \%$ coconut water. $(\mathrm{n}=15)$.

\begin{tabular}{|c|c|c|c|c|}
\hline \multirow[t]{3}{*}{$\begin{array}{l}\text { Treatments } \\
\text { 6-BA }\left(\mathrm{mg.L}{ }^{-1}\right)\end{array}$} & \multicolumn{4}{|c|}{ Explant regeneration responses } \\
\hline & \multicolumn{2}{|c|}{ Leaf-disc (\%) } & \multicolumn{2}{|c|}{ Root segments (\%) } \\
\hline & Day 28 & Day 56 & Day 28 & Day 56 \\
\hline $1(0.0)$ & $0.00 \mathrm{C}$ & $0.00 \mathrm{~B}$ & $55.00 \mathrm{~A}$ & $71.67 \mathrm{~A}$ \\
\hline $2(0.5)$ & $29.33 \mathrm{~A}$ & $54.66 \mathrm{~A}$ & $60.00 \mathrm{~A}$ & $70.00 \mathrm{~A}$ \\
\hline $3(1.0)$ & $13.33 \mathrm{BC}$ & $41.33 \mathrm{~A}$ & $46.67 \mathrm{~A}$ & $76.36 \mathrm{~A}$ \\
\hline $4(1.5)$ & $13.33 \mathrm{AB}$ & $56.00 \mathrm{~A}$ & $50.90 \mathrm{~A}$ & $76.36 \mathrm{~A}$ \\
\hline $5(2.0)$ & $0.00 \mathrm{C}$ & $11.42 \mathrm{~B}$ & $25.00 \mathrm{~B}$ & $50.00 \mathrm{~B}$ \\
\hline
\end{tabular}

Different letters in each column indicate significant differences of mean values $(\mathrm{p}<0,05 \%)$.

\section{Seedlings}

In this trial, the repetition was composed of one seedling per tube, so the response referring to the organogenic capacity was not analyzed statistically since it is an event frequency (Table 3). As in leaf discs, the organogenic response in the absence of 6-BA was null by day 28 and very low (13\%) by day 56. All seedlings presented bud formation in the roots by day 56 whenever cultivated in a 0.5 mg. $\mathrm{L}^{-1}$ 6-BA medium (Table 3 ). The presence of 6-BA, in MS medium, induced shoot formation from three explants (Table 2). The effciency of organogenesis no significant difference between the 6-BA concentrations tested. However, in the absence of the plant regulator, the mean number was significantly lower. In comparing Table 2 data, regarding root segment and seedling, one observes that when the root is isolated from the aerial plant part, the number of buds formed is higher, even in the absence of a plant regulator. The removal of the aerial part seems to promote the auxin/cytokinin balance favorable to cytokinin, accordingly leading to bud formation. These two explant sources and the responses obtained in the absence of the regulator can constitute an interesting model for studies on integrated growth of stems and roots. 
Table 2 - Effect of 6-BA on the mean number of shoot per explants of Passiflora cincinnata Mast. about the day 56 of culture on MS medium supplemented with $5 \%$ coconut water. $(n=15)$.

\begin{tabular}{cccc}
\hline Treatments & \multicolumn{3}{c}{ Mean number of shoots/explant } \\
\cline { 2 - 4 } 6-BA $\left(\right.$ mg. $\left.^{-1}\right)$ & Leaf disc & Root segments & Seedlings \\
\hline $1(0.0)$ & $0.0000 \mathrm{~B}$ & $2.2500 \mathrm{~B}$ & $0.3200 \mathrm{~B}$ \\
$2(0.5)$ & $3.8933 \mathrm{~A}$ & $5.1167 \mathrm{~A}$ & $3.8800 \mathrm{~A}$ \\
$3(1.0)$ & $2.3200 \mathrm{~A}$ & $4.9667 \mathrm{AB}$ & $4.8857 \mathrm{~A}$ \\
$4(1.5)$ & $1.9600 \mathrm{~A}$ & $4.5636 \mathrm{AB}$ & $3.8933 \mathrm{~A}$ \\
$5(2.0)$ & $0.2000 \mathrm{~B}$ & $1.4500 \mathrm{C}$ & $4.0133 \mathrm{~A}$ \\
\hline
\end{tabular}

Different letters in each column indicate significant differences of mean values $(\mathrm{p}<0,05 \%)$.

According to Peres and Kerbauy (2000) the ability to form stem buds in roots ex vitro reflects the competence to in vitro regeneration in this type of explant (Peres et al. 2001). In fact, it was verified in this study bud formation in root segments and in intact roots of the seedlings.

In practical application terms, either for cloning or for genetical modification, an explant class presenting a higher number of regenerated buds, likely to derive plants, is obviously the ideal.

The results for leaf disc explants follow those of the organogenic explant number. That is, the best treatments, which had no statistical difference, were found by day 56 , at $0.5,1.0$ and $1.5 \mathrm{mg} . \mathrm{L}^{-1} 6$ BA. Apparently, root segments were the ones producing the largest number of buds per explant, and in this case the $0.5 \mathrm{mg} . \mathrm{L}^{-1}$ 6-BA was the best, with no statistical difference from that of 1.0 and $1.5 \mathrm{mg} . \mathrm{L}^{-1}$ 6-BA. Thus, although the hormone-free treatment produced an equivalent number of regenerative explants to those treated with up to $1.5 \mathrm{mg} . \mathrm{L}^{-1} 6$-BA, the number of buds per explant was lower (Table 2) in these hormone treatments (Table 3).

Through these results and at the conditions in which the experiments were carried out, one concludes that the root segment explant with one dose of $0.5 \mathrm{mg} . \mathrm{L}^{-1}$ 6-BA is ideal to regenerate Passiflora cincinnata plants.

Table 3 - Effect of 6-BA on the frequency of organogenic explants (seedling) of Passiflora cincinnata Mast. about the day 28 and 56 of MS medium with $5 \%$ coconut water. $(n=15)$.

\begin{tabular}{ccc}
\hline Treatments & Frequency (\%) \\
\cline { 2 - 3 } 6-BA (mg.L $\left.\mathbf{L}^{-1}\right)$ & Day 28 & Day 56 \\
\hline $1(0.0)$ & 0 & 13.33 \\
$2(0.5)$ & 93.33 & 100.00 \\
$3(1.0)$ & 80.00 & 93.33 \\
$4(1.5)$ & 70.00 & 86.66 \\
$5(2.0)$ & 70.00 & 80.00 \\
\hline
\end{tabular}

\section{ACKNOWLEDGEMENTS}

We thank Fundação de Amparo à Pesquisa do Estado de São Paulo (FAPESP) for the grant awarded (02/05940-7) and Research Support (00/05780-4). Mrs Marli K. M. Soares and Mrs Milene Binatti Ferreira for the technical assistance.

\section{RESUMO}

Diferentes concentrações de 6-benziladenida (6BA) foram usadas para a indução de brotos in vitro em três tipos de explantes: discos foliares, segmentos de raiz e plântula obtidos da germinação de sementes in vitro de Passiflora cincinnata Mast. A concentração de $0,5 \mathrm{mg} . \mathrm{L}^{-1}$ foi a mais adequada para os três explantes, porém, o tempo e a via (direta/indireta) de formação da gema diferiu para cada tipo de explante. Nas plântulas utilizadas como explante houve a formação de gemas a partir da raiz primária. Os eventos histológicos que levaram a formação de um novo órgão, via meristemóides (centros meristemáticos) foram descritos. Nos discos foliares a origem foi indireta, com formação de 
calo a partir das células subepidérmicas das camadas de parênquima clorofiliano. Nos segmentos de raiz e nas raízes das plântulas, a organogênese direta apresentou duas origens, a partir do periciclo, nas raízes com início da estrutura secundária, e a partir do câmbio vascular, nas raízes com estrutura secundária já estabelecida. Também nos segmentos de raiz observou-se a via indireta cujo calo resultou da proliferação do periciclo.

\section{REFERENCES}

Agra, M. F.; Locatelli, E.; Rocha, E. A.; Baracho, G. S. and Formiga, S. C. (1996), Plantas medicinais nos Cariris Velhos, Paraíba, Parte II: subclasses Magnoliidae, Caryophyllidae, Dilleniidae e Rosidae. R. Bras. Farm., 3, 97-102.

Appezzato-da-Glória, B.; Vieira, M. L. C. and Dornelas, M. C. (1999), Anatomical studies of in vitro organogenesis induced in leaf-derived explants of passionfruit. Pesq. Agropec. Bras., 34, 2007-2013.

Becerra, D. C.; Forero, A. P. and Góngora, G. A. (2004), Age physiological condition of donor plants affect in vitro morphogenesis in leaf explants of Passiflora edulis f. flavicarpa. Plant Cell Tissue Organ Cult., 79, 87-90.

Biasi, L. A.; Falco, M. C.; Rodrigues, A. P. M. and Mendes, B. M. J. (2000), Organogenesis from internodal segments of yellow passionfruit. Sci. Agric., 57, 240-249.

Dornelas, M. C. and Vieira, M. L. C. (1994), Tissue culture studies on species of Passiflora. Plant Cell Tissue Organ Cult., 36, 211-217.

Hall, R. M.; Drew, R. A.; Higgins, C. M. and Dietzgen, R. G. (2000), Efficient organogenesis of an Australian passionfruit hybrid (Passiflora edulis $x$ Passiflora edulis var. flavicarpa) suitable for gene delivery. Aust. J. Bot., 48, 673-680.

Kantharajah, A. S. and Dodd, W. A. (1990), In vitro micropropagation of Passiflora edulis (purple passionfruit). Ann. Bot., 65, 337-339.

Karnovsky, M. J. (1965), A formaldehydeglutaraldehyde fixative of high osmolality for use in electron microscopy. J. Cell Biol., 27, 137-138.
Melo, M. O.; Melo, M. and Appezzato-da-Glória, B. (2001), Histological of the callogenesis and organogenesis from root segments of Curcuma zedoaria Roscoe. Braz. Arch. Biol. Technol., 44, $197-$ 203.

Melo, M. O.; Melo, M. and Appezzato-da-Glória, B. (2000), Bauhinia forficata Link shoot regeneration: histological analysis of organogenesis pathway. Braz. Arch. Biol. Technol., 43, 431-436.

Monteiro, A. C. B.; Nakazawa, G. T.; Mendes, B. M. J. and Rodriguez, A. P. M. (2000), Regeneração in vitro de Passiflora suberosa a partir de discos foliares. Sci. Agric., 57, 571-573.

Murashige, T. and Skoog, F. (1962), A revised medium for rapid growth and bioassays with tobacco tissue cultures. Physiol. Plant., 15, 473-497.

Peres, L. E. P. and Kerbauy, G. B. (2000), Controle hormonal do desenvolvimento de raízes. Universa, 8 , 181-185.

Peres, L. E. P.; Morgante, P. G.; Vechi, C. A.; Kraus, J. E. and Van Sluys, M. A. (2001), Shoot regeneration capacity from roots and transgenic hairy roots of different tomato cultivars and wild related species. Plant Cell Tissue Organ Cult., 65, 37-44.

Reis, L. B.; Paiva Neto, V. B.; Picoli, E. A. T.; Costa, M. G. C.; Rego, M. M.; Carvalho, C. R.; Finger, F. L. and Otoni, W. C. (2003), Axillary bud development of passionfruit as affected by ethylene precursor and inhibitors. In Vitro Cell. Dev. Biol. Plant., 39, 618622.

Sakai, W. S. (1973), Simple method for differential staining of paraffin embedded plant material using toluidine blue O. Stain Technol., 48, 47-249.

São José, A. R. (1994), Maracujá, Produção e Mercado. UESB, Vitória da Conquista. pp. 255.

SAS Institute. SAS/STAT. (2000), User's guide. Realese 8.0. Cary: Statistical Analysis System Institute.

Sousa, J. S. I. and Meletti, L. M. M. (1997), Maracujá: espécies, variedades, cultivo. FEALQ, Piracicaba. pp. 179.

Van Staden and J.; Smith, A. R. (1978), The synthesis of cytokinins in excised roots of maize and tomato under aseptic conditions. Ann. Bot., 42, 751-753.

Vieira, M. L. C. and Appezzato-da-Glória, B. (2001), Fundamentos e Aplicações da cultura de tecidos no melhoramento. In: NASS, L. et al. (ed.) Recursos Genéticos e Melhoramento de Plantas. EMBRAPA, Rondonópolis-MT.pp.913-938. 
PÁGINA

EM

BRANCO 